\title{
Desain Konsep Tentang Konten Lokal Pada Televisi Lokal Untuk Mengembangkan Wisata Kuliner Kota Malang
}

\author{
Lian Agustina Setiyaningsih \\ Ilmu Komunikasi FISIP Universitas Merdeka Malang \\ Email : lian.agustina@unmer.ac.id
}

\begin{abstract}
Television is a mainstream media that is able to survive amid the crush of media on line. Television developments occur until in the area, giving rise to local television. Indonesian Broadcasting Commission (KPI) has set up procedures local television aired on the Broadcasting Law No. 32/2012 and P3 SPS. Where local television has a role to develop the potential of the region. This study focused on the potential and promotional messages of Culture and Tourism (Dikbudpar) Malang. It also dug local television perspective in understanding the local content, which will be the two concepts will be used as a reference for designing the concept of local content on local television to develop culinary wosata Malamg. The method in this study is qualitative. To get the data researchers are working with informants from Dikbudpar Malang and local television in Malang. The data is then analyzed using interactive model of Miles and Huberman and domain analysis Spradley. This study aims to provide inputs to the government of Malang and local television media on the design concept of local content that can be used to develop culinary tourism Malang.
\end{abstract}

Keywords: Local Content, Local Television and Development of Tourism

\begin{abstract}
Abstrak
Televisi merupakan media mainstream yang mampu bertahan di tengah himpitan media on line. Perkembangan televisi terjadi sampai di daerah, sehingga memunculkan televisi lokal. Komisi Penyiaran Indonesia (KPI) telah mengatur prosedur penayangan televisi lokal pada UU Penyiaran No. 32/2012 dan P3 SPS . Dimana televisi lokal memiliki peran untuk mengembangkan potensi daerah. Fokus penelitian ini pada potensi dan pesan promosi Dinas Kebudayaan dan Pariwisata (Dikbudpar) Kota Malang. Selain itu juga menggali perspektif televisi lokal dalam memahami konten lokal, yang nantinya kedua konsep tersebut akan dijadikan sebagai rujukan untuk mendesain konsep tentang konten lokal pada televisi lokal untuk mengembangkan wosata kuliner Kota Malamg. Metode dalam penelitian ini adalah kualitatif. Untuk mendapatkan data peneliti bekerja sama dengan informan dari Dikbudpar Kota Malang serta televisi lokal di Malang. Data tersebut kemudian dianalisis dengan menggunakan interactive model Miles dan Huberman serta analisis domain Spradley. Penelitian ini bertujuan untuk memberikan masukan bagi pemerintah Kota Malang dan media televisi lokal tentang desain konsep konten lokal yang dapat digunakan untuk mengembangkan wisata kuliner Kota Malang.
\end{abstract}

Kata Kunci : Konten lokal, Televisi Lokal dan Pengembangan Pariwisata 


\section{PENDAHULUAN}

Media mainstream yang masih bisa bersaing dengan media alternatif atau media online adalah televisi. Dalam praktiknya televisi mengalami perkembangan bentuknya yang disesuaikan dengan kondisi audiensnya. Televisipun diatur oleh Komisi Penyiaran Indonesia (KPI) dimana setiap daerah memiliki kesempatan yang sama untuk memiliki televisi lokal yang bisa difungsikan sebagai media pengembangan potensi daerah masingmasing. Seperti yang diamanatkan dalam UU Penyiaran No 32/2002 pasal 8 (2), bahwa televisi lokal yang bisa dijadikan sebagai media pengembangan potensi lokal daerahnya. Pengembangan potensi lokal tersebut bisa dicapai melalui penerapan konten lokal dalam siaran televisi lokal.

Pada praktiknya televisi nasional tidak selalu mewadahi dan memberikan informasi kepada masyarakat yang letaknya di daerah. Artinya bahwa informasi yang disajikan oleh televisi nasional tidak selamanya relevan dan bermanfaat bagi masyarakat di daerah. Seperti misalnya terlalu dominannya pemberitaan tentang ibu kota di televisi nasional tidak selalu relevan dengan kondisi audiens di masing-masing daerah. Merujuk pada penelitian terdahulu bahwa selain itu televisi lokal masih dijadikan sebagai media alternatif untuk menggantikan televisi nasional dalam mengakses informasi dan melakukan pengembangan bagi masyarakat. (Mirza, 2011:15)

Untuk memperpanjang peran membutuhkan upaya agar televisi lokal bisa bertahan dan menjadi media promosi pariwisata daerah. Upaya yang bisa dilakukan adalah dengan meningkatkan mutu siaran lokal sehingga televisi lokal bisa menjadi tuan di rumahnya sendiri. Strategi yang bisa dilakukan dalam menggali identitas lokal sebagai potensi unggul pengembangan televisi lokal, di antaranya adalah dengan melakukan fungsionalisasi lokalitas dan kemandirian lokal, pemanfaatan bahasa sebagai strategi pemasaran identitas lokal, dan optimalisasi televisi lokal sebagai media dokumentasi budaya. (Adi, 2012: 893)

Melihat fenomena tersebut, konten lokal pada televisi lokal menjadi modal dasar dalam mengembangkan kualitas televisi. Hal tersebut juga telah diatur dalam Peraturan KPI tentang Standar Program Siaran (SPS) pasal 68 dan UU Penyiaran 4 pasal 8 terhadap televisi lokal yang berdiri sendiri maupun yang memiliki system jaringan. Konten lokal dijelaskan meliputi : siaran jurnalistik, program faktual dan program non faktual untuk mengembangkan potensi daerah.

Seluruh televisi lokal di Malang juga memiliki fungsi yang sama yakni mengembangkan potensi Kota Malang. Dalam praktiknya televisi lokal di Kota Malang telah berusaha mewujudkan konten lokal walaupun memang belum maksimal. Upaya yang harus dilakukan adalaha Kota Malang harus memiliki televisi lokal yang bisa dijadikan sebagai media lokal untuk meningkatkan kualitas parwisata Kota Malang agar bisa mengembangkan 
potensi lokal daerahnya. Pengembangan potensi lokal tersebut bisa dicapai melalui penerapan konten lokal dalam siaran televisi lokal. Dengan kata lain televisi lokal yang dimaksud adalah dengan konten lokal yang berbasis kearifan lokal di Kota Malang.

Kota Malang memiliki Tribina Cita yakni menggambarkan kota pendidikan, industri dan pariwisata. Saat ini Malang sedang mengembangkan pariwisatanya sebagai bentuk pengembangan potansi daerahnya. Pariwisata di Kota Malang terdiri dari tiga sektor yakni kuliner, religi dan minat khusus. Pariwisata di sektor kuliner mengalami perkembangan yang sangat signifikan. Hal ini dikarenakan berkaitan dengan pengembangan ekonimi masyarakat yang bisa dirasakan secara langsung dan perputarannya sangat cepat. Namun, realitas yang terjadi bahwa wisata kuliner ini belum terekspos secara signifikan. Dan informasi di media lokal masih tersentralisasi pada tempattempat tertentu saja sehingga akan membuat kejenuhan informasi dan kehilangan daya tariknya. (http://www.malangkota.go.id/halaman/ 1606072).

Berkaca pada program televisi lokal di Malang, promosi pariwisata di sektor kuliner masih belum terlihat efektif. Hal ini bisa dilihat dari konten lokal di dalam televisi lokal tidak disajikan secara proporsional. Televisi lokal yang dimiliki Malang harusnya menjadi media promosi kuliner untuk meningkatkan potensi pariwisata Malang. Sehingga dibutuhkan konten media yang bisa mempromosikan wisata kuliner Malang melalui televisi lokal. Oleh karenanya peneliti dalam penelitian ini ingin membuat sebuah desain konsep yang berkaitan dengan konten lokal untuk mengembangkan pariwisata kuliner di Kota Malang. Konten yang dimaksud sesuai dengan kaidah penyajian konten dalam media massa yakni berdasarkan keakurasian dan keaktuaktualan, kejelasan, human interest, kedekatan, serta dampak.

\section{KERANGKA KONSEPTUAL Konten Lokal Pada Televisi Lokal}

Istilah konten lokal dikenal semenjak televisi lokal berkembang secara pesat di berbagai daerah. Konten lokal atau muatan lokal diperkenalkan oleh Komisi Penyiaran Indoenasia (KPI) melalui Pedoman Prilaku Penyiaran dan Standart Program Siaran (P3 SPS) tahun 2012. Dalam pasal 68 disebutkan bahwa muatan atau konten lokal wajib diterapkan dalam televisi lokal. Konten lokal ini dimaksudkan untuk membantu audiens dalam melakukan pemaknaan pesan. Sehingga memabantu meningkatkan efektifitas pengunaan televisi lokal dan meningkatkan pemahaman audiensnya.

$$
\text { Dalam UU Penyiaran No }
$$
32/2012 pada pasal 8(2) menyebutkan bahwa konten lokal dalam televisi lokal meliputi siaran jurnalistik, program faktual dan program non faktual. Dan secara jelas disebutkan bahwa keberadaan televisi lokal melalui pengayaan konten lokal akan membantu mengembangkan potensi sebuah daerah. 
Berkaitan dengan hal tersebut keberadaan konten lokal dinilai sebagai alat yang bisa memperkaya kreatifitas media lokal khususnya televisi.

Regulasi yang demikian memiliki sedikit kesamaan dengan di Kanada, bahwa menurut Ken \& Toby (2001: 3) Di Kanada, misalnya, Undang-Undang Penyiaran memberikan bahwa sistem penyiaran "akan efektif dimiliki dan dikendalikan oleh Kanada, "berkontribusi" pemeliharaan dan peningkatan identitas nasional dan kedaulatan budaya. Dengan kata lain Ken menjelaskan konten lokal menjadi penopang dalam melestarikan budaya.

Konten dianggap penting karena dalam kajian ilmu komunikasi konten merupakan representasi pesan yang akan disampaikan kepada audiens atau komunikan. Sehingga konten tersebut tersampaikan maka komunikasi akan berjalan dengan efektif. Hal ini senada dengan pendapat Everret M. Rogres dimana kegiatan komunikasi massa memiliki dimensi isi (content) yang didiseminasikan, yaitu berupa pengetahuan dan produk baru dimaksud yang juga termasuk bahan dan informasi pendukung lainnya. (Rogrers, $1995: 127)$

Hal tersebut diperkuat oleh Severin dan Tankard (1992) bahwa komunikasi massa adalah sebagian ketrampilan (skill), seni (art) dan ilmu (science). Tanpa dimensi seni menata pesan, tidak mungkin media surat kabar, majalah, radio siaran, televisi dan film dapat memikat perhatian khalayak, yang pada akhirnya pesan tersebut dapat mengubah sikap, pandangan, dan perilaku komunikan. (Severin dan Tankard, 1992 : 107).

Mencermati

pentingnya

keberhasilan dalam berkomunikasi maka dalam kegiatan memaknai sebuah pesan di media massa yang perlu diperhatikan adalah seni dalam menyusun konten media itu sendiri. Di dalam perkembangan televisi lokal pesan-pesannya tentunya juga harus bisa dimaknai secara efektif oleh audiens. Konten lokal memiliki peran untuk membantu masyarakat dalam memaknai pesan di televisi lokal. Hal ini dianggap penting karena berkaitan dengan kerangka berpikir masyarakat mengenai daerah mereka termsauk faktor kedekatan (proximity) dalam memahami sebuah pesan dalam media lokal. Hasil penelitian terdahulu terkait strategi pengembangan televisi lokal mengatakan bahwa melalui fungsionalisasi lokalitas dan kemandirian lokal serta pemakaian bahasa lokal bisa dijadikan sebagai strategi untuk mengembangkan konten lokal dalam televisi lokal. (Adi, 2009: 893)

Berawal dari hal tersebut konten lokal bisa dianggap sebagai wujud dari fungsionalisasi dan kemandirian lokal. Konten lokal bisa dalam bentuk bahasa lokal yang dapat merepresentasikan identitas daerah. Fungsi bahasa dalam televisi salah satunya adalah sebagai alat promosi, di mana bahasa menjadi alat permainan atau manipulasi oleh pihak televisi untuk menjual barang produksi. Sehingga dalam penelitian ini membuat desain konten lokal merupakan salah satu upaya yang dapat dilakukan untuk mengembangkan 
pariwisata kuliner Kota Malang.

Terdapat beberapa kaidah yang harus diperhatikan dalam menyusun konten di televisi. Sama seperti karya jurnalistik, produk televisi lokal juga harus memperhatikan kaidah tersebut agar mencapai output yang maksimal. Kaidah-kaidah yang sering dipakai dalam menyusun konten antara lain berupa keakurasian dan keaktuaktualan, kejelasan, human interest, kedekatan, serta dampak. Bentuk konten lokal yang bisa dipakai adalah berupa bahasa, bentuk acara, angle pengambilan gambar, warna yang dipakai dalam menyampaikan pesan serta skrip atau scenario. Seluruh hal tersebut harus berdasrkan Panduan Kerja Jurnalis dimana disebutkana bahwa konten harus mengandung nilai berita.Suatu peristiwa dan pendapat memiliki nilai berita jika memenuhi unsur berikut :

1. Penting (significance): ada manfaat bagi pembaca.

2. Besar (magnitude): kejadian besar, terutama dilihat secara kuantitatif dan dampaknya bagi manusia.

3. Aktualitas: peristiwa yang baru terjadi dan belum dimuat media lain.

4. Kedekatan (proximity): peristiwa yang dekat dengan pembaca secara geografis maupun emosional.

5. Tenar (prominence): menyangkut hal-hal yang terkenal.

6. Human interest (manusiawi): kejadian yang memberikan sentuhan perasaan, hiburan, melepaskan ketegangan.

7. Lengkap (komprehensif): menjawab pertanyaan tentang apa, siapa, di mana, apabila, mengapa, dan bagaimana. (Jurnalisme Positif : Panduan Kerja

Jurnalis, $2012: 23$ )

\section{Pariwisata Kuliner Kota Malang}

Sejak tahun 1962, Kota Malang telah ditetapkan sebagai Kota Pelajar/Pendidikan, Kota Industri dan Kota Pariwisata. Ketiga hal tersebut kemudian dikenal dengan Tribina Cita Kota Malang yang merupakan tiga citacita Kota Malang untuk pengembangan potensi daerah. Tribina Cita menjadikan tumpuannya untuk mengembangkan tiga bidang yang menonjol di Kota Malang. Salah satu bidang yang saat ini intens dikembangkan adalah Pariwisata. Semenjak karesidenan Malang dipecah menjadi tiga daerah, Kota Malang memiliki tantangan tersendiri dalam mengembangkan bidang Pariwisata. Kota Malang juga harus berkompetisi dengan dua daerah pecahannya yakni Kota Batu dan Kabupaten Malang.

Pada dasarnya Kota Malang memiliki potensi alam yaitu pemandangan alam yang elok serta hawa yang sejuk, teduh dan asri serta bangunan-bangunan kuno peninggalan Belanda, Kota Malang layak menjadi tujuan wisata bagi wisatawan dalam maupun luar negeri. Berbagai pilihan tempat perbelanjaan, baik yang bersifat tradisional maupun modern yang tersebar di berbagai penjuru kota sangat menunjang Kota Malang sebagai Kota Pariwisata. Perkembangan pusat-pusat perbelanjaan modern ini seiring dengan perkembangan kawasan perumahan 
yang melaju dengan pesat seakan tidak ada lagi lahan yang tersisa di Kota Malang. Di era otonomi daerah dan era globalisasi saat ini upaya pembangunan di segala bidang yang telah dilaksanakan merupakan sebuah langkah awal peningkatan citra, posisi dan peran Kota Malang dalam percaturan hubungan antar Kota, antar Propinsi, maupun antar Bangsa. Sekaligus merupakan sebuah peluang dan harapan yang bisa memberi manfaat bagi masyarakat Kota Malang sendiri. (http://www.malangkota.go.id/halaman/ 1606072)

Fenomena di atas merupakan alasan Kota Malang dalam menjawab tantangan kompetisi dengan daerah lainnya. Dinas Kebudayaan dan Pariwisata (dinbudpar) Kota Malang juga telah berupaya untuk mengklasifikasikan jenis pariwisata yang bisa dinikmati. Bidang Pariwisata dibagi menjadi tiga sektor yakni wisata kuliner, wisata religi dan wisata minat khusus. Wisata minat khusus merupakan wisata yang menekankan pada heritage (bangunan peninggalan zaman Belanda). Sedangkan wisata religi meliputi wisata yang menonjolkan bangunan bernuansa keagamaan. Sedangkan wisata kuliner merupakan wisata yang mengekspose kuliner khas Malang. (Dinbudpar, 2013)

Kondisi sama terjadi di India, menurut Praveenkumar (2014:190) dalam penelitiannya Pariwisata memperoleh pendapatan melalui devisa. valuta asing ini diperlukan untuk pemerintah untuk mengurangi defisit dan media bertanggung jawab untuk menciptakan kesadaran tentang tujuan wisata yang tersedia di India untuk wisatawan luar negeri. industri media bekerja dengan hotel, agen perjalanan, operator tur, maskapai penerbangan dan berbagai instansi pemerintah untuk membawa pendapatan negara dengan mempromosikan pariwisata. Tanpa bantuan dari media dan dukungan banyak tempat akan tetap belum diselidiki sebagai kesadaran tentang tempat ini sangat minim untuk orang asing.

\section{Keterkaitan Konten Lokal pada Televisi Lokal dengan Perkembangan Pariwisata Kuliner Kota Malang}

Televisi lokal merupakan media untuk mengembangkan potensi daerah. Kota Malang dapat menggunakan televisi lokal sebagai media promosi pariwisata di bidang kuliner. Sehingga bisa dikatakan bahwa televisi lokal yang ada bisa menjadi alternatif untuk menyampaikan pesan sesuai dengan kemampuan dan menjadi media alternatif dalam muatan atau konten lokal. Kelebihan dari televisi lokal lebih memungkinkan penayangan tokoh, lembaga dan perusahaan lokal. Selain itu televisi lokal juga menampung kearifan lokal dinamika masyarakat dan tayangan lebih dekat dengan emosional pemirsa.

Kelemahan televisi lokal ada pada jangkauan siaran dan jam tayang masih terbatas. Serta materi penayangan juga menjenuhkan jika terlalu banyak waktu luang. Meskipun demikian kelemahan tersebut bisa dijawab dengan memaksimalkan implementasi konten yang sifatnya lokal. Karena pada dasarnya potensi televisi lokal memiliki 
gaya lokalitas tersendiri yang menjadi daya tarik bagi audiensnya. Konten lokal yang dimaksud adalah berbasis pada kearifan lokal dari sebuah daerah. (http://www.dotsemarang.com/televisilokal-media-alternatif-mengembangkanbudaya-pariwisata-daerah/)

$$
\text { Konten lokal dalam }
$$

penerapannya berkaitan dengan pola komunikasi yang efektif. Mc. Crosky Larson dan Knapp mengatakan bahwa komunikasi yang efektif dapat dicapai dengan mengusahakan ketepatan (accuracy) yang paling tinggi derajatnya antara komunikator dan komunikan. Komunikasi yang lebih efektif terjadi apabila komunikator dan komunikan terdapat persamaan dalam pengertian, sikap dan bahasa (konten). Komunikasi dapat dikatakan efektif apa bila komunikasi yang dilakukan dimana :

1. Pesan dapat diterima dan dimengerti serta dipahami sebagaimana yang dimaksud oleh pengirimnya.

2. Pesan yang disampaikan oleh pengirim dapat disetujui oleh penerima dan ditindaklanjuti dengan perbuatan yang diminati oleh pengirim.

3. Tidak ada hambatan yang berarti untuk melakukan apa yang seharusnya dilakukan untuk menindaklanjuti pesan yang dikirim. (Crosky, Larson dan Knapp, 1993 : 64-65)

Kota Malang melalui Dinbudpar memiliki tujuan untuk mewujudkan Kota Malang sebagai destinasi Pariwisata yang bermartabat. Berdasarkan hal tersebut memformulasi disain konsep konten lokal yang tepat untuk televisi lokal merupakan solusi meningkatkan promosi wisata kuliner Kota Malang. Merujuk pada penelitian sebelumnya pembuatan konten lokal bisa membuahkan hasil jika diiringi dengan stretegi fungsionalisasi dan kemandirian lokal dalam membuat konten lokal. (Adi, 2009 : 893)

Memfungsikan nilai lokal adalah dengan memanfaatkan potensi wisata kuliner dan mengekspos destinasi wisata kuliner yang sudah ditetapkan oleh Dinbudpar Kota Malang. Sedangkan kemandirian lokal bisa diimplementasikan dengan pendistribusian konten lokal melalui televisi lokal. Artinya bahwa ada pemanfaatan terhadap media lokal untuk mengembangkan wisata kulinernya. Tentunya dalam pembuatan konten lokal yang berbasis kuliner Kota Malang tetap merujuk pada pedoman penulisan jurnalistik yang selalu dijadikan patokan dalam menyusun pesan dalam media massa. Pedoman ini dipakai karena obyek konten lokal yang akan dibentuk merupakan sekumpulan fakta yang akan disajikan untuk meningkatkan wisata kuliner Kota Malang.

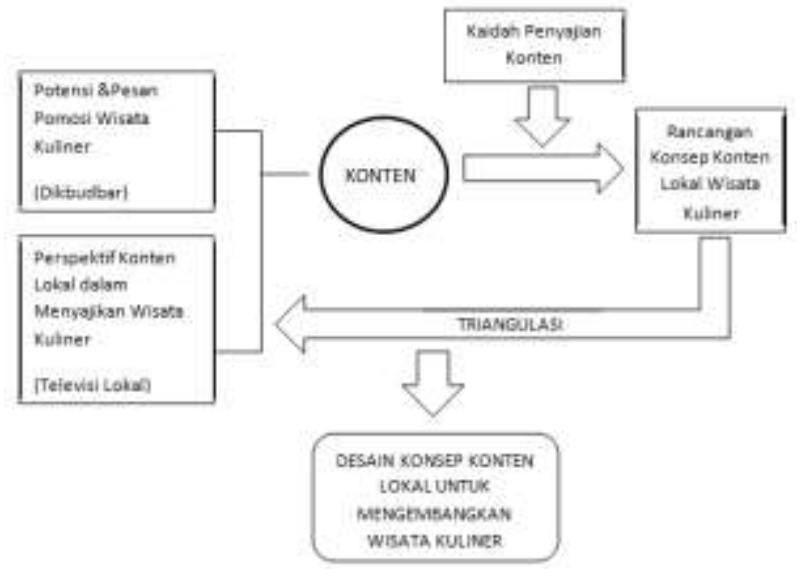




\section{Metodologi Penelitian}

Dalam mendesain konsep konten lokal yang digunakan untuk mengembangkan wisata kuliner Kota Malang, menggunakan metode penelitian kualitatif. Penelitian kualitatif pada hakekatnya adalah mengamati orang dalam lingkungan hidupnya, berinteraksi dengan mereka dan berusaha memahami bahasa dan tafsiran tentang dunia sekitar (Sugiyono, 2010 : 180) Penelitian ini akan mengamati isi atau konten yang berbasis lokalitas (lokal) pada televisi lokal di Kota Malang. Kemudian mengumpulkan data terkait kebutuhan penyusunan konten lokal untuk meningkatkan wisata kuliner Kota Malang. Melalui metode kualitatif ini akan muncul komponen pembentuk konten lokal yang akan digunakan sebagai media pengembangan wisata kulinar Kota Malang. Fakta-fakta empirik akan didapatkan untuk mendukung pembuatan desain konten lokal.

Teknik pengambilan sample penelitian kualitatif ini dilakukan secara purposive sample, yakni pengambilan sample sumber data dengan pertimbangan tertentu. (Sugiono, 2010 : 53-54). Pertimbangan umum yang dipakai adalah karena sumber data tersebut memiliki kompetensi untuk menjawab permasalahan yang menjadi fokus penelitian ini. Sumber data atau informan yang dilibatkan dari Dikbudpar Kota Malang adalah kepala dinbudpar, seksi pengembangan produk dan promosi pariwisata dan seksi promosi pariwisata. Pertimbangannya adalah ketiga orang yang berada di jabatan masing-masing berkaitan dengan pengembangan wisata kuliner Kota Malang.

Sedangkan televisi diambil tiga dari 11 televisi yang ada dikota Malang yakni Malang TV, JTV dan Gajayana TV. Sesuai observasi awal yang dilakukan oleh peneliti, ketiga televisi tersebut memiliki konsep dalam menayangkan programnya.

Teknik analisis data mengikuti konsep Miles dan Huberman serta Spradley. Menurut Miles dan Huberman aktivitas dalam analisis data terdiri dari data redauction, data display, dan conclusion drawing/verification.

(Sugiono, $2010: 183$ )

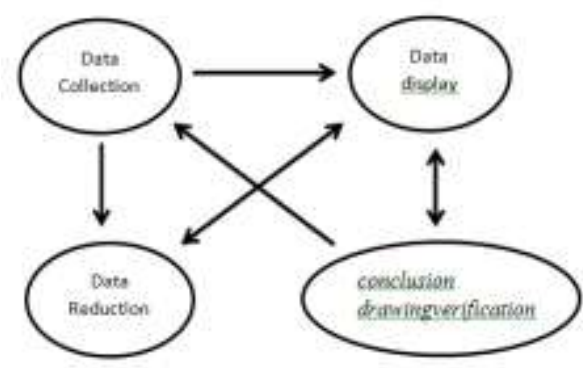

Komponen dalam analisis data (interactive model)

Analisis data kualitatif selanjutnya menggunakan teknik domain Spradley. Teknik ini membantu peneliti dalam menentukan domain atau kategorisasi dalam menyususn konsep konten lokal yang dibutuhkan.

\section{Hasil dan Pembahasan}

\section{Analisis Data}

Penelitian ini menggunakan metode wawancara untuk mengumpulkan data, wawancara dilakukan kepada pihak yang memiliki kaitan dengan promosi wisata kuliner 
Kota Malang. Informasi didapatkan dari dua lembaga yakni yang pertama lembaga pemeritahan daerah Dinas Kebudayaan dan Pariwisata Kota Malang. Lembaga kedua adalah televise local yang terletak di Kota Malang yakni JTV (Jawa Timur TV), Gajayana TV serta Malang TV.

\section{Disbudpar Kota Malang}

Memiliki julukan kota wisata memberikan tugas tersendiri bagi Disbudpar Kota Malang untuk memelihara dan terus mengembangkan brand tersebut. Malang sudah mengusung icon Bakso Kota Malang sejak berpuluh-puluh tahun yang lalu dan kemudian disambut dengan ikon keripik buah, sayur dan ubi-ubian yang telah berkembang sepuluh tahun terakhir ini. Disbudpar memiliki tugas untuk mengembangkan dan menggali potensi wisata Kota Malang. Wisata kuliner sudah menjadi wisata yang mengakar disetiap daerah dan menjadi daya tarik unggulan di kota-kota besar lainnya. Peneliti telah melakukan wawancara dengan disbudpar untuk menggali konsep yang dimiliki dan cara mengimplementasikan konsep tersebut dan bersinergi dengan media lokal khususnya televisi. Dari wawancara yang dilakukan berdasarkan instrument penelitian (wawancara) mendapatkan beberapa data tentang :

a. Konsep pesan untuk wisata kuliner yang dimiliki Disbudpar Kota Malang.

b. Konsep yang selama ini digunakan oleh Disbudpar di Kota Malang. c. Media yang digunakan untuk menerapkan konsep tersebut.

d. Rencana konsep baru untuk mengembangkan potensi wisata kuliner di Kota Malang.

Data yang didapatkan dari hasil wawancara mengenai konsep pesan untuk wisata kuliner yang dimiliki Disbudpar Kota Malang meunjukkan bahwa

1. Disbudpar Kota Malang masih belum memiliki desain konsep terbaru tentang promosi wisata kuliner. Hal ini terlihat dari jawaban yang diberikan pada saat proses wawancara yakni Disbudpar memiliki konsep untuk mengembangkan wisata kuliner di Kota Malang. Konsep tersebut dibagi dalam dua sektor yakni sektor internal dan sektor eksternal. Sektor internal melibatkan seluruh internal pemerintah kota malang khususnya internal Dibudpar kota, sedangkan aspek eksternal berasal dari luar Disbudpar kota Malang meliputi : media massa dan penduduk sekitar serta pelaku usaha kuliner.

2. Melalui sektor tersebut, peneliti menanyakan lebih lanjut tentang desain konsep yang dimiliki oleh Disbupar Kota Malang. Pihak internal masih ingin mengembangkan wisata kuliner yang sudah bertahun-tahun dilakukan yakni menonjolkan ikon Bakso malang yang menjadi khas utama. Sedangkan snack camilan kripik menjadi second opinion untuk menopang ikon bakso Malang. Dengan kata lain, masih 
belum memiliki konsep baru tentang promosi wisata kuliner Kota Malang. Konsep yang diterapkan measih mengacu pada konsep terdahulu, hal ini dikeranakan masih dianggap sebagai konsep yang cocok untuk tetap dikembangkan di Kota Malang.

3. Disbudpar masih belum menyadari kompetisi yang luar biasa dari daerah lainnya terlebih daerah tetangga yakni Kota Batu. Batu sudah memiliki konsep tematik untuk wisata kuliner mereka. seperti misalnya daerah wisata kuliner dikategorikan dengan wisata buah dan makanan. Di Kota Malang masih belum ada konsep detail seperti yang dimiliki oleh Kota Batu.

4. Untuk menopang kegiatan promosi Disbudpar kota Malang menggandeng media sebagai implementasi pengembangan kerjasama sektor eksternal. Media yang paling sering digunakan adalah print media (media cetak) yang berupa koran harian, pemilihan ini karena mudah diakses. Wartawan koran harian sering kali standby di kantor Disbudpar Kota Malang, sehingga memiliki akses yang mudah ketika ada kebutuhan.

5. Pemanfaatan media lokal masih sebatas ada koran. Disbudpar Kota Malang masih belum memiliki kecenderungan menggunakan media elektronik khususnya televisi lokal bila dibandingkan Pemerrintah Kota (Pemkot)
Malang. Wali Kota Malang sering menggunakan televisi lokal untuk meliput kegiatan kunjungan kerja dan acara lainnya yang dilakukan pemkot Malang.

6. Fokus Kota Malang hanya terletak pada dua kuliner saja yakni bakso dan kripik atau snack. Belum ada gambaran untuk mengembangkan ke wisata kuliner lainnya. Alasannya adalah bahwa sejak berpuluh-puluh tahun yang lalu, bakso menjadi makanan ikon kota malang, brand bakso sudah melekat pada kota malang.

\section{Malang TV}

Sebagai televisi lokal, Malang TV memiliki tanggung jawab sosial untuk membantu Disbudpar Kota Malang dalam melakukan promosi wisata kuliner. Hal ini dikarenakan televisi lokal merupakan media yang menjadi tumpuan utama di era otonomi daerah. Hasil wawancara yang dilakukan kepada produser program secara umum adalah Malang TV memiliki ide untuk mendukung program Disbudpar dan mempromosikan wisata kuliner Kota Malang. Melalui konsep yang dimiliki, Malang TV siap bersinergi dengan pemerintahan khususnya dengan Disbudpar.

Media lokal memiliki fungsi yang jauh efektif karena terletak pada faktor kedekatan (proximity) antara pesan, media dan audeinsnya. Malang TV juga menerapkan asas tersebut, sehingga berawal dari asas proximity, menghasilkan desain konten lokal 
dalam sebuah acara atau program televisi yang bertujuan untuk mempromosikan potensi wisata kuliner.

Konsep wisata kuliner yang merepresentasikan kota malang bagi Malang TV terletak pada konsep program acara yang ada sekarang bernama warung anda memiliki keterkaitan dengan promosi wisata kuliner. Malang TV memiliki program acara "Warung Anda" yang sudah berjalan sekitar 3 tahun belakangan ini. Konsep acara tersebut masih ingin dipertahankan oleh Malang TV mengingat Malang TV masih ingin mempertahankan konsep keberagaman dalam menyajikan pesan di setiap acara yang mereka miliki.

Penjelasan konten lokal oleh produser program "kalau kami ingin memberikan penyajian acara yang rancak mulai dari restoran hotel bintang lima, café, depot makan hingga penjual kaki lima". Hal tersebut mempertimbangkan jenis wisatawan yang datang ke kota Malang. Hal tersebut akan membantu memberikan informasi kepada wisatawan yang heterogen selera dan asalnya. Sedangkan hal yang dipertimbangkan dalam membuat konten kuliner untuk promosi adalah yang utama audiens.

Sinergi yang bisa dilakukan dengan program pemerintah adalah memberikan penawaran kerjasama untuk sinergi konsep program. Melakukan kegiatan diskusi awal untuk menggabungkan konsep lalu menindaklanjuti dengan proposal pengajuan kerjasama setelah mengawinkan konsep dan bekerja sama dengan lokasi yang akan dijadikan sebagai destinasi wisata kuliner. Bagi Malang TV keterlibatan pemerintah melalui Disbudpar Kota merupakan unsur terpenting dalam bersinergi untuk menciptakan cara yang efektif dalam mempromosikan potensi wisata kuliner yang ada di Kota Malang.

\section{Gajayana TV}

Gajayana TV merupakan televisi lokal yang terhitung muda bila dibandingkan dengan televisi lokal lain yang ada dalam penelitian ini yakni Malang TV dan JTV. Meskipun tergolong baru, namun Gajayana TV sudah banyak berkontribusi dalam mengenalkan potensi wisata di Kota Malang. Seperti misalnya mengiklankan destinasi wisata yang ada di Kota Malang, meskipun sifatnya tidak terlalu massif. Televisi ini juga memiliki program acara kuliner yang meneyrupai program "Warung Anda" di Malang TV. Hal tersebut menjadi pintu masuk untuk mengembangkan desain konten lokal yang nantinya bisa mempromosikan kuliner.

\section{Hasil wawancara mengenai} konsep wisata kuliner yang merepresentasikan kota malang adalah dengan membuat program yang berkelanjutan dengan tema yang berbeda di setiap bulannya. Konsep yang akan ditampilkan adalah makanan lokal yang ada di kota Malang. Pada awal program menonjolkan desain konten lokal yang berbasis pada cuaca dan kondisi udara di Kota Malang. Malang memiliki karakteristik udara yang dingin dan sejuk. Sehingga yang 
ingin ditonjolkan di awal program adalah kuliner yang hangat dan cocok dikonsumsi di daerah yang dingin dan sejuk. Berangkat dari kuliner Bakso yang menjadi ikon utama wisata kuliner Kota Malang, konsep yang ingin ditampilkan di awal program adalah menyajikan beberapa destinasi wisata kuliner Bakso yang terekomendasi baik dari segi rasa, harga hingga spesifikasi tempatnya.

Terdapat tiga faktor dalam membuat konten kuliner untuk promosi wisata kota Malang, yang pertama adalah audiens. Seperti televisi lokal sebelumnya juga meletakkan audiens sebagai faktor utama yang harus diperhatikan dalam membuat desain konten lokal program kuliner. hal ini dikerakan audiens merupakan indikator utama keberhasilan sebuah program acara televisi. Faktor kedua adalah pemilihan tempat yang merepresentasikan kearifan lokal Kota Malang. Dan yang ketiga adalah iklan yang masuk dalam program tersebut untuk sirkulasi keuangan. Durasi menjadi faktor keempat yang digunakan untuk menentukan desain konten lokal. Pemilihan pembawa acara yang keren dan tidak meninggalkan budaya Malang yakni budaya walikan menjadi faktor terakhir.

\section{JTV (Jawa Pos Media TV)}

Berbeda dengan televisi lokal sebelumnya, JTV merupakan perintis pertama televisi lokal di Indonesia. Di jawa Timur JTV merupakan televisi
Lokal yang tertua, sehingga jika dilihat dari program acara yang dimiliki hingga saat ini terlihat sudah matang hampir menyerupai televisi nasional yang ada di Indonesia. Di awal beroperasinya JTV, memiliki program kuliner "Galeri Kuliner", namun saat ini tidak memiliki program kuliner khusus. Pesan wisata kuliner diikutkan dengan program berita dan program yang lainnya. Meskipun demikian JTV memiliki keinginan untuk mendukung Kota Malang dalam mempromosi dan mengembangkan wisata kulinernya.

Konsep wisata kuliner yang dianggap merepresentasikan Kota Malang, menurut JTV adalah yang menitik tekankan pada desain konten lokal. Konten lokal yang dimaksud adalah yang berkaitan erat dengan audiens yang melihat. Seperti misalnya, akhir-akhir ini Malang menjamur café dimana-mana. Hal tersebut juga memberikan kompetisi sendiri bagi anak muda yang sering kali menjadi targetnya. Wisatawan yang datang ke Malang juga mencari café unik yang tidak ditemukan di daerah lain. Sehingga JTV membagi konsep acara menjadi dua yakni segmen anak muda dan keluarga. Sehingga program yang akan dibuat juga berdasarkan segmen tersebu. Perlu adanya kategorisasi merupakan indikator keberhasilan yang mudah dilihat. Jika segmen ada pada anak muda maka lokasinya adalah café. Sedangkan untuk target audiens keluarga tempatnya ada pada tempat resto untuk keluarga yang nyaman dan hangat. 
Aspek lain yang peru diperhatikan adalah durasi program 30 menit yang terbagi 3 segmen dengan rincian 6 menit iklan dan sisanya 24 menit dibagi menjadi 3 segmen. Ini merupakan contoh durasi ideal yang diberikan JTV, begitu juga jika kita perhatikan di televise nasional. Tindakan konkrit lainnya adalah membuat membuat dami (contoh program mulai dari awal sampai akhir mulai bumper hingga closing). Dami dibahas dalam rapat umum untuk digodog menjadi lebih matang. Pembagian program per daerah atau per jenis makanan, misalnya makanan tradisional,tempo dulu, makanan modern, dan lainnya.

Café adalah priotitas untuk promo wisata terdapat tema komik serta komunitas yang menjadi kekuatan promo wisata kuliner yang kekinian. Dari segi budget atau anggaran, produksi awal untuk liputan digratiskan, selanjtnya jika sudah terkenal bisa dikasih tarif untuk biaya produksinya. Seperti misalnya mencari sponsor dari makanan atau minuman, iklan still text (iklan berjalan) dan di credit title.

Hal yang dipertimbangkan dalam membuat konten kuliner untuk promosi wisata kota malang adalah target audiens. Tindak lanjut dari program ada pada penggunaan media sosial yang optimal seperti facebook, twiter, youtube, instagram, marchendise (pada acara off air). Umpan balik dari audiens bisa langsung di lihat melalui respon di media sosial, sebab hal tersebut menjadi tolak ukur atau rating acara.
Pemasangan iklan juga menjadi aspek yang diperhatikan dalam menyusun program. Hal lain yang memiliki keterkaitan dengan desain konten lokal adalah menekankan pada budaya Malang yakni Walikan. Istilah Malangan akan tetap dijadikan sebagai daya tarik dalam acara tersebut. Kemudian atribut yang melekat dari Malang seperti misalnya menggunakan warna biru, warna dasar arema untuk warna dominan pada acara tersebut.

\section{Pembahasan}

\section{Potensi dan Pesan Promosi Dinas Kebudayaan dan Pariwisata Kota Malang}

Malang memiliki potensi kuliner, sehingga akhir-akhir ini Malang memberikan sentuhan lain dari potensi kulinernya. Dari Bakso bergeser ke Kripik Tempe, Buah dan Sayur. Ikon yang muncul jika berkunjung ke Kota Malang adalah membawa pulang oleholeh aneka Kripik. Setiap kios atau tokoh oleh-oleh hampir pasti menyediakan aneka kripik tempe, buah bahkan sayur. Konsep ikon bakso atau bakwan dan kripik masih dipertahankan oleh Disbudpar Kota Malang dalam langkah promosi wisata kuliner. Namun, seiring dengan berkembangnya city branding di Indonesia, hal tersebut menjadi ancaman bagi perkembangan wisata kuliner di Kota Malang, sebab di setiap daerah saat ini berlomba-lomba mengeksplorasi potensi wisata kulinernya. Tidak hanya sekedar menonjolkan ikon kuliner, namun juga menjelaskan destinasi dan 
mengeksplorasi destinasi wisata kuliner untuk menambah pendapatan daerah umumnya, khususnya untuk meningkatkan perekonomian rakyat atau masyarakat setempat.

Disbudpar telah mempublikasikan destinasi wisata kuliner yang lekat dengan legenda dan sejarah di web yang dikelolanya. Destinasi tersebut hendaknya disertai dengan konsep promosi yang syarat akan konten lokal. Sehingga wisatawan yang datang berkunjung tidak hanya sekerdar menikmati sajian makanan atau minumannya, namun juga menikmati sejarah serta budaya yang melekat pada tempat tersebut. Untuk menuju ke arah sana, Disbudpar Kota Malang sudah memiliki strategi yang dilakukan di tataran internal dan eksternal. Di internal melibatkan seluruh pemerintah kota untuk mendukung program pengembangan wisata kuliner. Sedangkan di eksternal melibatkan masyarakat kota Malang serta media lokal. Mulai dari koran lokal hingga televisi lokal mampu menjadi media yang efektif untuk bersinergi mempromosikan wisata kuliner. Dari beberapa masukan yang diberikan oleh televisi lokal di Kota Malang, Dispudpar hendaklah memiliki konsep yang bisa berinergi dengan media lokal setempat agar media relations bisa tercapai secara efektif. Era cyber saat ini menjadi peluang besar jika ingin mengembangkan wisata kuliner. Sebab, kelebihan media yang berbasis internet yakni menipiskan batas ruang dan waktu, sehingga publikasi bisa dilakukan secara massif.

\section{Perspektif Televisi Lokal Konten Lokal Wisata Kuliner Kota Malang}

Dalam menyajikan pesan promosi kuliner, televisi lokal memperhatikan aspek pesan dari tataran tingkat kemudahan pesan dipahami, tidak adanya hambatan yang berarti hingga pesan bisa diterima oleh audiens. Dengan kata lain konten lokal merupakan bagian dari pesan. Dan dalam membuat sebuah konten lokal harus memperhatikan ketepatan penyampaian. Disamping itu kesamaan dan kedekatan juga merupakan unsur pendukung konten lokal untuk mengembangkan wisata kuliner Kota Malang. Konten pesan juga harus dimengerti, diterima serta terbebas dari hambatan terdistribusikannya pesan.

Televisi lokal memiliki cara kreatif untuk mengemas promosi kuliner agar tidak terkesan sebagai acara iklan atau promosi semata. Untuk memberikan tampilan yang berbeda, setiap televisi lokal yang menjadi informan dalam penelitian menonjolkan konsep konten yang memiliki muatan lokal yang tidak monoton. Desain konsep acara yang bermuatan lokal memiliki tujuan jangka panjang untuk bisa bersinergi dengan Disbudpar Kota Malang. Malang TV memiliki konsep program yang mengutamakan audiens heterogen. Sehingga dalam menentukan keutamaan konten lokal lebih menekankan pada lokasi kuliner yang beragam dari bintang lima hingga kaki lima. Aspek lain yang menjadi perhatian adalah penggunaan bahasa campuran antara istilah Malangan 
dengan bahasa Indonesia. Malang TV masih menggunakan konsep program yang sudah ada yakni "Warung Anda" dimana dalam pemilihan spot dan jenis makanan dilakukan secara rancak. Karena ingin menyasar seluruh elemen dalam masyarakat.

Berbeda dengan Gajayana TV menekankan pada aspek ikon Bakso atau bakwa yang menjadi legenda di Malang. Konten lokal dimunculkan dari sisi jenis makanan yang sudah menjadi ikon Kota Malang yang berlangsung berpuluh-puluh tahun yang lalu. Alasan memunculkan jenis makanan ini adalah ingin bersinergi dengan konsep yang dimiliki pemerintah, sehingga penggabunngkan konsep bisa menjadi jauh lebih efektif dan mudah. Tidak jauh dari ikon bakso atau bakwan, konten lokal yang diangkat adalah cuaca dan kondisi udara yang sejuk dan dingin. Menggunakan asas proximity inilah Bakso bisa diangkat karena kondisi cuaca dan udara yang dingin, sehingga makanan yang cocok adalah makanan hangat yang berkuah. Durasi program yang singkat serta penggunaan bahasa walikan akan juga disajikan sebagai muatan lokal di program kuliner. Tentunya akan diberikan keterangan terkait arti bahasa walikan tersebut.

JTV merupakan pioneer televisi lokal yang melejit sukses dalam pengembangan program. Acara di JTV memiliki standart televisi nasional, dan sudah terbukti diterima di audiens. Dalam hal promosi kuliner, JTV menekankan kearifan lokal dalam membuat pesan yang ada dalam program acaranya. Konten lokal yang ditekankan ada pada target audiens, yang dibagi menjadi dua yakni anak muda dan keluarga. Untuk sasaran anak muda maka yang dijadikan sebagai destinasi wisatanya adalah café yang memiliki banyak bentuk dan menjamur di Malang. Sedangkan untuk keluarga adalah restiran yang nyaman dan hangat bagi keluarga. Bahasa walikan juga menjadi komoditas dalam menerapkan konten lokal dalam programnya. Insert gambar tentang budaya malang akan disajikkan sebagan dalam acara sebagai bentuk penghargaan budaya lokal kota Malang.

Selain itu, JTV juga sudah memiliki gambaran detail tentang acara untuk promosi kuliner. Durasi acara juga menjadi penentu keberhasilan penyajian acara. Untuk melihat keberhasilan acara maka JTV menggunakan media sosial untuk mengetahui umpan balik audiens dan kualitas acaranya. Media sosial yang dimiliki sekaligus menjadi barometer keberhasilan acara tersebut, pasalnya dunia maya menjadi kehidupan kedua masyarakat informasi transformative saat ini. Dalam menjalankan programnya, Disbudpar dilibatkan dalam menyokong data wisata kuliner untuk mengembangkan daerah atau lokasi yang menjadi target promosi wisata kuliner Kota Malang.

\section{Desain Konsep Konten Lokal Wisata Kuliner Kota Malang}

Indonesia memiliki konsep utama yang diterapkan di masingmasing daerah, yakni konsep wisata 
kuliner yang disesuaikan dengan kearifan lokal masing-masing daerah. Kegiatan besarnya diberi nama "Wonderful Indonesia Culinary \& Shopping Festival 2016". Kegiatan tersebut menjadi penghubung dan bisa dikembangkan Disbudpar Kota Malang untuk mendongkrak wisata kuliner Kota Malang.agenda yang ada dalam kegiatan tersebut adalah pameran makanan dan jajanan nusantara serta digabungkan dengan kegiatan pemaran fashion yang berbasis kelokalan daerah.

Selain kegiatan di atas, keterlibatan televisi lokal menjadi faktor penting dalam melakukan publikasi wisata kuliner Kota Malang. Tiga televisi lokal yang sudah disebutkan di atas telah menyumbangkan konsep program acara kuliner yang memiliki muatan konten lokal di dalamnya. Hal ini dimaksudkan agar acara tersebut tidak hanya sekedar menginformasikan makanan atau minuman yang menjadi destinasi wisata kuliner. Namun, juga menggali dan memberikan informasi sejarah dan kelegendaannya. Malang TV, Gajayana TV dan JTV memberikan masukan konten lokal yang menekankan pada penggunaan bahasa Malangan dalam menyajikan program. Konten kedua adalah pada pemilihan pembawa acara yang sesuai dengan jenis program tanpa meninggalkan gaya Malangannya.

Dari sisi pesan yang disampaikan, ketiga televisi lokal tersebut kompak mengekspos makanan Malang yang disertai dengan cerita legenda atau sejarah yang melekat pada makanan atau tempat wisata kuliner tersebut. Konten keempat yang ditampilkan adalah adanya jenis makanan yang bisa menjadi ikon utama kota Malang, sehingga pada saat mengekspose ada satu titik temu yang bisa merepresetasikan Malang sebagai Kota Kuliner. Konten terakhir adalah yang memperhatikan target audiens, yakni konten lokal yang memperhatikan latar belakang audiens serta kecenderungan life style atau gaya hidup audiens. Dalam hal audiens, ketiga televisi lokal tersebut memiliki perspektif yang berbeda. Meski demikian, Disbudpar Kota Malang siap melakukan sinergi dengan televisitelevisi lokal. Artinya bahwa Disbudpar menerima masukan dari tiga televisi lokal tersebut dan siap berkolaborasi untuk mewujudkan wisata kuliner Kota Malang. Bagi Disbudpar media lokal merupakan patner yang dapat membantu mensosialisasikan konsep yang dimilikinya. Penekanan Disbudpar Kota Malang adalah mengkombinasikan konsep ikon bakso atau bakwan malang dan kripik dengan konsep televisi lokal yang menekankan pada konten lokal.

\section{Penutup}

Dari analisis data dan pembahasan di bab sebelumnya dapat disimpulkan sebagai berikut:

1. Kota Malang memiliki potensi wisata kuliner yang besar dan masih belum maksimal dalam pengelolaan dan promosi wisata kuliner Kota Malang. Meskipun Dinas Kebudayaan dan Pariwisata Kota Malang telah memiliki daftar destinasi wisata kuliner di websitenya, namun 
belum ada konsep baru yang mengembangkan dan meningkatkan publikasi wisata kuliner.

2. Pemerintah Kota Malang melalui Dinas Kebudayaan dan Pariwisata Kota Malang memiliki konsep turun temurun untuk melestarikan ikon Bakso atau Bakwan Malang. Konsep ini dirasa sebagai konsep yang tepat yang masih belum bia digantikan dengan konsep yang lainnya. Namun terdapat konsep lain sebagai penopang yang sudah berkembang beberapa tahun terakhir yakni memunculkan ikon keripik baik berbahan tempe, buah hingga sayur. Hal ini digunakan sebagai pelengkap ikon Bakso atau Bakwan Malang. Keripik adalah ikon oleh-oleh yang mudah dibawa dan memiliki ke khasan Kota Malang.

3. Televisi lokal memiliki perspektif tentang konten lokal yang berbeda dengan Dinas Kebudayaan dan Pariwisata Kota Malang. Perbedaan terletak pada upaya penyajian dan pengembangan konten lokal melalui program promosi wisata kuliner yang dilakukan oleh televisi lokal. Sebab, televisi lokal memiliki kontribusi yang besar dalam melakukan publiasi secara massif wisata kuliner. Desain konsep lokal yang dihasilkan meliputi penggunaan bahasa Malangan, pemilihan pembawa acara dengan gaya
Malangan, mengekspos makanan Malang yang disertai dengan cerita legenda atau sejarah yang melekat pada makanan atau tempat wisata kuliner tersebut, serta target audiens.

4. Perbedaan desain konsep yang memiliki muatan konten lokal antara Dinas Kebudayaan dan Pariwisata Kota Malang dengan televisi lokal dapat disinergikan menjadi konsep program acara kuliner untuk mendongkrang potensi dan animo wisatawan. Sinergi dilakukan dengan mengkolabirasikan desain konsep yang syarat akan nilai lokal di atas dengan konsep dinas yakni mengedepankan ikBakso atau Bakwan Malang dan Kripik Kota Malang.

\section{Saran}

Berdasarkan hasil penelitian, pembahasan hasil penelitian dan keterbatasan pada hasil penelitian ini, dapat dikemukakan beberapa saran sebagai berikut :

1. Bagi Dinas Kebudayaan dan Pariwisata Kota Malang, sinergi konsep ini menjadi jalan untuk semakin memudahkan mengembangkan potensi wisata kuliner di Kota Malang serta meminimalisir cara konvensional yang digunakan untuk meningkatkan kualitas wisata kuliner yang mampu berkompetisi dengan daerah lainnya. 
2. Bagi Televisi Lokal di Kota Malang, dalam pelaksanaannya nantinya lebih mengutamakan konten lokal dari pada unsur keuntungan atau bisnis, sehingga menghasilkan tayangan yang berkualitas dan mampu menjadi mitra Pemerintah Kota Malang.

3. Bagi Audiens Televisi Lokal di Kota Malang, melakukan evaluasi dan monitoring atas tayangan wisata kuliner Kota Malang, sebagai bentuk partisipasi aktif literacy media serta mengembalikan fungsi media massa pada fungsi yang ideal.

\section{REFERENSI}

Adi, Tri Nugroho. 2009. Strategi Mengemas Identitas Lokal dalam Mengembangkan televisi lokal. (hal. 891-902) Dalam Prosiding Menggagas Pencitraan Berbasis Kearifan Lokal. Tersedia dalam http://www. komunikasi. unsoed. ac.id. diakses 21 Februari 2015.

Anshori, Y. \& Satriya, D.G. 2008. Sparkling Surabaya Pariwisata dengan Huruf L. Malang: Bayumedia Publishing.

Mc. Crosky, Larson dan. Knapp, M.L. 1996. Efektivitas Komunikasi Interpersonal. Jakarta : Salemba

Mirza, Feriandi. 2011. Eksistensi TV Lokal diantara dominasi tv nasional oleh (hal. 11-21)
Dalam

http://www.slideshare.net/efmirz a/eksistensi-tv-lokal-di-antaradominasi-tv- nasional. diakses 21 Februari 2015.

Moleong, Lexy J. 2005. Metodologi Penelitian Kualitatif. Bandung : PT Remaja Rosda Kaya

Praveenkumar, S. 2014. Role of Media in the Promotion of Tourism Industry in India. Global Review of Research in Tourism, Hospitality and Leisure Management India. 2014 Vol: 1 Issue 3.

Rogers, Everett, M. 1995. Diffusions of Innovations, Forth Edition. New York: Tree Press

Severin, Joseph. \& Tankard. James W. 1992. Communication Theories: Origins, Methods, and Uses in the Mass Media. Werner. Published by Longman Pub Group

Sugiyono. 2010. Metode Penelitian Kualitatif. Bandung : CV. Alfabeta

\section{Sumber lain :}

Bhattacharjee, Ken. \& Mendel, Toby. Marcht 2001. Local Content Rules in Broadcasting. Diakses di:https://www.article19.org/pdf s/publications/local-contentrules.pdf. Pada 28 April 2016. 
Disbudpar. Diakses di :

http://budpar.malangkota.go.id/i

ndex.php?option=com_content\&

view $=$ category $\& i d=2$. Pada 24

Februari 2015

Koran Semarang Kota. Diakses di :

http://www.dotsemarang.com/tel

evisi-lokal-media-alternatif-

mengembangkan-budaya-

pariwisata-daerah. Pada 24

Februari 2015.

Pemerintah Kota Malang, diakses di :

http://www.malangkota.go.id/hal

aman/1606072. Pada 24

Februari 2015.

Jurnalisme Positif : Panduan Kerja

Jurnalis, 2012 : 23 UU

Penyiaran RI No 32 /

Tahun2012, Komisi Penyiaran

Indonesia

2012. Pedoman

Prilaku Penyiaran dan Standart

Program Siaran (P3 SPS) tahun

2012

Televisi lokal dan

pencitraan http://jurnal.isi-

ska.ac.id/index.php/acintya/articl

e/view/17/15 diakses oktober

2016 